\title{
Ocurrence and risk factors associated with Mycoplasma agalactiae infection in dairy goat herds of Paraíba State, Brazil ${ }^{1}$
}

\begin{abstract}
Rodrigo A.T. Matos ${ }^{2 *}$ (D), Sandra B. Santos ${ }^{3}$, Renato V. Alves ${ }^{4}$, Ednaldo J. Silva ${ }^{2}$, Melânia L. Marinho ${ }^{4}$, José Wilton P. Júnior ${ }^{5}$, Rinaldo A. Mota ${ }^{3}$ and Felicio Garino Júnior ${ }^{6}$

ABSTRACT.- Matos R.A.T., Santos S.B., Alves R.V., Silva E.J., Marinho M.L., Júnior J.W.P., Mota R.A. \& Garino Júnior F. 2019. Ocurrence and risk factors associated with Mycoplasma agalactiae infection in dairy goat herds of Paraíba State, Brazil. Pesquisa Veterinária Brasileira 39(2):9398. Graduate Program in Veterinary Medicine, Centro Universitário Cesmac, Rod. Divaldo Suruagy s/n, Marechal Deodoro, AL 57160-000, Brazil. E-mail: rodrigoatmatos@gmail.com

Mycoplasmosis is a disease that may cause severe economical losses in goat and sheep herds, and it is associated with mastitis, polyarthritis, agalactia, conjunctivitis, pneumonia and reproductive failure. The objective of this study was to determine the occurrence of Mycoplasma agalactiae in milk samples and investigate the main risk factors associated with infection in goats from farms of the state of Paraíba, Brazil. For Mycoplasma agalactiae diagnosis, 251 milk samples were submitted to DNA extraction using a commercially available kit, following the manufacturer's instructions and Polymerase Chain Reaction (PCR) was performed. In addition, questionnaires were applied to identify the main risk factors associated with contagious agalactia. Out of the two hundred fifty-one samples analyzed, 50 (19.9\%, I.C. 15.1-25.4\%) were PCR positive for M. agalactiae. In the risk factors analysis, some associations were observed for the following variables: size of the herd $(\mathrm{P}<0.001$, $\mathrm{OR}=7.1$, I.C. 2.4-20.6), replacement of farm animals $(\mathrm{P}<0.001, \mathrm{OR}=4.7$, I.C. 1.8-12.2) and participation of animals in fairs and exhibitions $(\mathrm{P}=0.029, \mathrm{OR}=2.0$, I.C.1.0-3.9). The results allowed confirming the occurrence of Mycoplasma agalactiae in milk samples of goats from Paraíba. Therefore, it is strictly necessary to monitor dairy goat flocks and to raise the awareness of farmers about the economic importance of the disease, since it causes severe economic losses for producers of the state. Identification of risk factors is essential for adoption of control measures and for the correction of the management factors in farms where there are animals with positive diagnosis, avoiding, so, pathogen dissemination.
\end{abstract}

INDEX TERMS: Mycoplasma agalactiae, infection, mycoplasmosis, polymerase chain reaction, milk, goats, caprine, bacterioses.

\footnotetext{
${ }^{1}$ Received on May 16, 2018.

Accepted for publication on September 16, 2018.

${ }^{2}$ Laboratório de Doenças Infecciosas, Departamento de Medicina Veterinária, Centro Universitário Cesmac, Rod. Divaldo Suruagy s/n, Marechal Deodoro, AL 57160-000, Brazil. *Corresponding author: rodrigoatmatos@gmail.com

${ }^{3}$ Laboratório de Doenças Infecciosas, Departamento de Medicina Veterinária, Universidade Federal Rural de Pernambuco (UFRPE), Av. Dom Manoel de Medeiros s/n, Recife, PE 52171-900, Brazil.

${ }^{4}$ Unidade Acadêmica de Medicina Veterinária, Universidade Federal de Campina Grande (UFCG), Av. Universitária s/n, Patos, PB 58708-110, Brazil.

${ }^{5}$ Unidade Acadêmica de Medicina Veterinária, Universidade Federal Rural de Pernambuco (UFRPE), Av. Dom Manoel de Medeiros s/n, Recife, PE 52171-900.

${ }^{6}$ Laboratório Animal VetLab, Rua Aluízio de Queiroz 15, Sala 3, Patos, PB 58704-745.
}

RESUMO.- [Ocorrência e fatores de risco associados à infecção por Mycoplasma agalactiae em rebanhos caprinos leiteiros do estado da Paraíba, Brasil.] As micoplasmoses ocasionam prejuízos econômicos nas criações de ovinos e caprinos, e estão associados com quadros de mastite, poliartrite, agalaxia, conjuntivite, pneumonia e falhas reprodutivas. Objetivou-se neste estudo determinar a ocorrência de Mycoplasma agalactiae em amostras de leite e investigar os principais fatores de risco associados à infecção em caprinos provenientes de propriedades rurais do estado da Paraíba, Brasil. Para o diagnóstico de Mycoplasma agalactiae, foram analisadas 251 amostras de leite, que foram submetidas à 
extração do DNA genômico usando um kit comercial, seguindo as recomendações do fabricante. Para diagnóstico da infecção utilizou-se a Reação em Cadeia da Polimerase (PCR). Além disso, foram aplicados questionários para identificar os principais fatores de risco associados infecção à agalaxia contagiosa. Das 251 amostras analisadas, 50 (19,9\%; I.C. 15,1-25,4\%) foram positivas na PCR para M. agalactiae. Observaram-se na análise dos fatores de risco, algumas associações para as seguintes variáveis: tamanho do rebanho $(\mathrm{P}<0,001 ; 0 R 7,1)$, reposição de animais da propriedade $(\mathrm{P}<0,001$; OR 4,7) e participação dos animais em feiras e exposições $(\mathrm{P}=0,029$; OR 2,0). Os resultados permitiram confirmar a ocorrência do Mycoplasma agalactiae em amostras de leite de caprinos da Paraíba. Portanto, é necessário o monitoramento dos rebanhos caprinos leiteiros e a conscientização dos produtores rurais para a importância econômica da doença, visto que a mesma acarreta severos prejuízos econômicos para os produtores do estado. A identificação dos fatores de risco são imprescindíveis para a adoção de medidas de controle e para a correção dos fatores de manejo em propriedades que tenham animais com diagnóstico positivo, evitando assim, a disseminação do patógeno.

TERMOS DE INDEXAÇÃO: Mycoplasma agalactiae, infecção, micoplasmoses, reação de cadeia de polimerase, leite, caprinos, bacterioses.

\section{INTRODUCTION}

Mycoplasmosis are diseases caused by bacteria of the class Mollicutes, which are considered the smallest self-replicating prokaryotes without cellular walls (Chazel et al. 2010). In goats, the main mycoplasmosis are contagious caprine pleuropneumonia, CCPP (OIE 2014) and contagious agalactia of ovine and caprine animals, CAOC (OIE 2013). This disease can cause mastitis, agalactia, polyarthritis, keratoconjunctivitis and, occasionally, abortion and pneumonia (Gómez-Martín et al. 2013). The main agent of CAOC is Mycoplasma agalactiae, although other species, such as: $M$. capricolum subsp. capricolum, $M$. putrefaciens and $M$. mycoides subsp. capri can also cause the disease (Madanat et al. 2002, Gil et al. 2003).

Infection takes place orally, via respiratory tract or at the mammary area, and, after a period of bacteremia, it disseminates to the eyeball, mammary gland, joints, tendons, uterus and lymph nodes. Among the early signals, the most important are the birth of infeasible offspring and abortions. Transplacental infection has been described in goatlings (Azevedo et al. 2012). Infection by $M$. agalactiae spreads across the herd by direct contact with infected animals and in the environment via contaminated milk and milking equipment, ocular discharge and the hands of milkers. There are also reports of venereal transmission (Madanat et al. 2001).

CAOC is geographically distributed throughout Europe, Western Asia, USA and Northern Africa, and is endemic in most Mediterranean countries (Gil et al. 2003). In Brazil, M. agalactiae was isolated from sick goats in 2001, in the state of Paraiba (Azevedo et al. 2006). Reports of the disease in the states of Pernambuco and Rio Grande do Norte have been published after that (Azevedo 2005), and it has also been diagnosed in the microregion of Cariri Paraibano (Bandeira et al. 2008). However, there is neither recent study nor data available on the current situation of the disease in the State of Paraíba, nor are there are not even studies about the risk factors in Paraiba which may be associated with the infection by $M$. agalactiae in dairy goats. The aim of this research was to verify the occurrence of $M$. agalactiae in milk samples and to investigate the major risk factors associated with the infection in goats coming from farms in microregions of the State of Paraíba, in Brazil.

\section{MATERIALS AND METHODS}

Area of study and sampling. In the period from March 2016 to April 2017, 13 dairy goat farms, located in the Western and Eastern Paraíba Cariri, Western Curimataú and Eastern Seridó microregions and in the municipalities of Gurjão (07 $14^{\prime} 48^{\prime \prime} \mathrm{S}$ and $36^{\circ} 29^{\prime} 22^{\prime \prime} \mathrm{W}$ ), Juazeirinho (07 04' $06^{\prime \prime}$ S and $36^{\circ} 34^{\prime} 40^{\prime \prime} \mathrm{W}$ ), Monteiro (07' 53' 22" S and 37 07' 12" W), Nova Floresta $\left(06^{\circ} 27^{\prime} 19^{\prime \prime} \mathrm{S}\right.$ and $\left.36^{\circ} 12^{\prime} 12^{\prime \prime} \mathrm{W}\right)$, Prata $\left(07^{\circ} 41^{\prime} 27^{\prime \prime} \mathrm{S}\right.$ and $37^{\circ} 04^{\prime}$ 49" W), São Sebastião do Umbuzeiro (08 09' 08" S and $\left.37^{\circ} 00^{\prime} 37^{\prime \prime} \mathrm{W}\right)$ and Zabelê ( $08^{\circ} 04^{\prime} 32^{\prime \prime} \mathrm{S}$ and $37^{\circ} 05^{\prime}$ 54" W) were selected and visited using a convenience-oriented sampling. The selection took into account the occurrence of clinical signs suggesting infection by Mycoplasma agalactiae.

The size of the sample for the prevalence study was determined considering an anticipated prevalence of $10 \%$ for the infection in goats (Santos et al. 2014), which determined a minimum sampling of 138 goats, considering a level of significance of $95 \%$ and a statistical error of $5 \%$ (Thrusfield 2004).

The following formulas were used to calculate the number of animals:

$$
n=1,96^{2} \cdot P_{e s p .}\left(1-P_{e s p}\right) / d^{2} ; n_{\text {ajust }}=(N \times n) /(N+n)
$$

Where: $\mathrm{n}=$ minimum number of goats to be sampled, $\mathrm{N}=$ total number of goats in the herd, $\mathrm{P}_{\text {esp }}=$ anticipated prevalence, $\mathrm{d}^{2}=$ absolute precision.

As the criterion for inclusion of goats in the sample, all females in lactation coming from farms with animals with signals suggesting infection were selected. A total of 251 samples were collected with a safety margin at the discretion of the authors. It was not possible to standardize the number of samples and goats per farm due to the significant differences in herd sizes and to the fact that some animals were not in the lactation period.

Collection of samples. In the 13 farms, 251 samples of milk from goats of the races Alpine American, British Alpine, Anglo-Nubian, Saanen, Alpine Parda, Toggenburg and mixed-race were collected. All the farms had animals with a history of sharp decrease in the production of milk. In four farms goats with a history of reproductive disorders were observed. For the collection of samples, udders were washed with a solution of sodium hypochlorite and soaked in iodized alcohol. A pool of both udders was then made, and a sample collected from each animal in sterile Falcon-type tubes containing $50 \%$ glycerinated saline solution added with Penicillin $(2.000 \mathrm{UI} / \mathrm{ml})$ was stored in freezers at $-20^{\circ} \mathrm{C}$ and $-80^{\circ} \mathrm{C}$ up to the moment of the molecular diagnosis.

Molecular diagnosis. Milk samples were aliquoted in volume of $300 \mu \mathrm{l}$ and genomic DNA was extracted using the "Wizard ${ }^{\circledR}$ Genomic DNA Purification Kit" (Promega) commercial kit, following the manufacturer's protocol. The quality and amount of DNA extracted were evaluated using an automatic quantifier 
(Multiscan Go, ${ }^{\circledR}$ ThermoScientific). The polymerase chain reaction (PCR) was done with the oligonucleotides described by Tola et al. (1997), $M a$ (FS1 5'-AAAGGTGCTTGAGAAATGCC-3' and FS2 5'-GTTGCAGAAGAAAGTCCAATCA-3'), which amplify a fragment of 375 base pairs of the gene 16SRNA of Mycoplasma agalactiae. For the reaction, $8 \mu \mathrm{L}$ of PCR Mix LGC ${ }^{\circledR} 2 \mathrm{X}$ (LGC Biotecnologia ${ }^{\circledR}$, Code 13-11250, Cotia/SP, Brazil) were used, containing: $200 \mathrm{mM}$ of each dNTP; $1.5 \mathrm{mM}$ of $\mathrm{MgCl}_{2}$; Taq DNA Polimerase (0.5U) in appropriate reaction concentration and buffer (Tris-HCl $\mathrm{pH}$ : 8.5, KCl); oligonucleotides at $30 \mathrm{pmol} ; 8 \mu \mathrm{L}$ genomic DNA and PCR water, totalizing a final volume of $25 \mu \mathrm{L}$ of reaction. The positive reaction control was the one isolated from Pernambuco Ma62 (BrPE62), and PCR water was used as negative control. The thermal profile used was the same described by Tola et al. (1997). The reactions were carried out using a Bioer XP Thermal Cycler ${ }^{\circledR}$ thermocycler (Bioer Technology Corporation LTDA, Hangzhou, China). PCR products were stained with Blue Green Loading Dye $I^{\circledR}$ (LGC Biotecnologia ${ }^{\circledR}$, Code 13-15009.06, Cotia/SP, Brazil) and submitted to 1.5\% agarose gel electrophoresis. Amplicons were displayed on transilluminator $\left({ }^{\circledR}\right.$ TransiluminatorLoccusBiotecnology L-Pix photodocumented).

Analysis of risk factors and statistics. For the study of risk factors, epidemiological questionnaires were applied containing objective questions to the producers about the general characteristics of farms and their productive, reproductive and sanitary management.

Data were expressed using absolute and relative frequencies. Interpretation of prevalence (high, average and low) was based on percentiles 25 and 75 of the percentages of goats which were positive in the herds. The analysis of herds evaluated the association between the history of clinical manifestations suggestive of CAOC by Mycoplasma agalactiae in the herds and the positive results for Mycoplasma agalactiae in PCR using Pearson's chi-square $\left(X^{2}\right)$ statistical test (Sampaio 1998). Regarding the analysis of animal risk factors, an univariate analysis of the variables of interest was first carried out using Fisher's exact X2 test, whenever necessary, and after that a logistic regression analysis was done using as dependent variable the result obtained in PCR (positive or negative). The independent variables considered in the model were those which showed statistical significance below 0.20 . This probability was stipulated so that possible risk factors of the event were not excluded from the analysis (Hosmer \& Lemeshow 1989). EpiInfo ${ }^{\mathrm{TM}} 7$ was used for statistical calculations and the level of significance adopted was 5.0\%.

Ethical aspects. The research was approved by the Research Ethics Committee (CEP) of Federal University of Campina Grande (UFCG) under protocol no. 296-2015.

\section{RESULTS AND DISCUSSION}

Among the 251 samples analyzed, 50 (19.9\%, I.C. 15.1-25.4\%) were positive in the PCR for Mycoplasma agalactiae, with eight positive farms (61.5\%) distributed among the following municipalities: Gurjão, Juazeirinho, Prata, São Sebastião do Umbuzeiro and Zabelê. The results per farm are shown in Table 1.

Farms A, F and M had high prevalences; the remainder showed average and low prevalence of CAOC, considering the percentiles of 25 and 75 . In the distribution by municipalities, prevalences were observed in the municipalities of Gurjão
(16.7\%), Juazeirinho (64.3\%), Prata (18.3\%), São Sebastião do Umbuzeiro (40.0\%) and Zabelê (12.5\%). In the municipalities of Monteiro and Nova Floresta, all the goats evaluated were negative for infection by $M$. agalactiae. The results of the analysis of the association of PCR with the history of clinical signs in the herds and of the risk factors associated with infection by Mycoplasma agalactiae in goats are shown in Table 2 and 3.

The prevalence of CAOC by Mycoplasma agalactiae in this study (19.9\%) was lower than that found by Azevedo et al. (2006) in Paraíba. These authors reported a prevalence of $100.0 \%$ in small ruminants after an outbreak of contagious agalactia in farms located in Paraíba, Brazil. The values were possibly different due to the occurrence of outbreaks in several farms studied by the authors. However, when compared with a study done by Bandeira et al. (2008), also in the state of Paraíba, a higher prevalence was found in goat milk than that observed by these authors, which was of $7.5 \%$ (9/120). This difference may be due to the number of animals and herds used in the survey, to the acquisition of animals from other regions of Brazil and to differences in handling between farms, since the studies were done in different farms, although some municipalities were the same. In the present study, a higher prevalence was observed in goat milk rather than that found by Alves et al.(2013) in the State of Pernambuco, which was of $3.7 \%(3 / 81)$. These same authors explain that the difference between the prevalence values is due to the different stages of mycoplasmosis in the herds studied. These same authors state that factors such as chronic or subclinical character of the disease and treatment of mastitis in herds with antibiotics for long periods may also have contributed to the differences between prevalences.

As for the clinical signs associated with the positive results of PCR for infection by Mycoplasma agalactiae, most variables presented a significant association with the diagnosis of CAOC, except for the variable regarding reproductive disorders, infertility and infertility associated with abortion $(P>0.05)$. Although, there have been association of cases of mastitis unresponsive to treatment and polyarthritis with the diagnosis of infection by $M$. agalactiae, it is not possible

Table 1. Frequency of positive dairy goats per property

\begin{tabular}{ccc}
\hline Property & N & Positivity \\
\hline A & 14 & $9(64.3 \%)$ \\
B & 45 & $12(26.7 \%)$ \\
C & 16 & $2(12.5 \%)$ \\
D & 11 & $0(0.0 \%)$ \\
E & 13 & $2(15.4 \%)$ \\
F & 20 & $7(35.0 \%)$ \\
G & 20 & $1(5.0 \%)$ \\
H & 26 & $0(0.0 \%)$ \\
I & 12 & $0(0.0 \%)$ \\
J & 13 & $0(0.0 \%)$ \\
L & 6 & $1(16.7 \%)$ \\
M & 40 & $16(40.0 \%)$ \\
N & 15 & $0(0.0 \%)$ \\
Total & 251 & $50(19.9 \%)$
\end{tabular}

$\overline{\mathrm{N}=\text { number }}$ of samples collected on the property. 
Table 2. Analysis of the association of the PCR results with the history of clinical manifestations in the goat herds

\begin{tabular}{|c|c|c|c|}
\hline Variables & $\mathrm{N}$ & $\begin{array}{c}\text { PCR } \\
\text { Positive }\end{array}$ & Value $\mathrm{P}^{\mathrm{A}}$ \\
\hline \multicolumn{4}{|c|}{ History of mastitis that does not respond to antibiotic therapy } \\
\hline Yes & 40 & $17(42.5 \%)$ & \multirow[t]{2}{*}{$<0.001^{*}$} \\
\hline No & 211 & $33(15.6 \%)$ & \\
\hline \multicolumn{4}{|c|}{ History of mastitis and polyarthritis at the same time } \\
\hline Yes & 40 & $17(42.5 \%)$ & \multirow[t]{2}{*}{$<0.001 *$} \\
\hline No & 211 & $33(15.6 \%)$ & \\
\hline \multicolumn{4}{|l|}{ Birth history of offspring with polyarthritis } \\
\hline Yes & 20 & $10(50.0 \%)$ & \multirow{2}{*}{$<0.001^{*}$} \\
\hline No & 231 & $40(17.3 \%)$ & \\
\hline \multicolumn{4}{|c|}{ History of pneumonias, polyarthritis, conjunctivitis, sudden death } \\
\hline Yes & 40 & $17(42.5 \%)$ & \multirow[t]{2}{*}{$<0.001^{*}$} \\
\hline No & 211 & $33(15.6 \%)$ & \\
\hline \multicolumn{4}{|l|}{ History of reproductive disorders } \\
\hline Yes & 85 & $29(34.1 \%)$ & \multirow[t]{2}{*}{$<0.001^{*}$} \\
\hline No & 166 & $21(12.6 \%)$ & \\
\hline \multicolumn{4}{|l|}{ What reproductive disorders } \\
\hline Infertility & 65 & $19(29.2 \%)$ & \multirow[t]{2}{*}{0.088} \\
\hline Infertility + abortion & 20 & $10(50.0 \%)$ & \\
\hline
\end{tabular}

${ }^{\mathrm{A}}$ Test X2; $\mathrm{N}=$ total of analyzed samples, 1 different database $(\mathrm{N}=85)$; * Significant association at the $5.0 \%$ level.

Table 3. Analysis of risk factors associated with Mycoplasma agalactiae infection

\begin{tabular}{|c|c|c|c|c|c|}
\hline \multirow[b]{2}{*}{ Variables } & \multirow[b]{2}{*}{$\mathrm{N}$} & \multirow{2}{*}{$\begin{array}{c}\text { PCR } \\
\text { Positive }\end{array}$} & \multicolumn{3}{|c|}{ Regression logistic } \\
\hline & & & Value P & $\begin{array}{c}\text { OR } \\
\text { (I.C. } 95 \% \text { ) }\end{array}$ & Value P \\
\hline \multicolumn{6}{|l|}{ Racial characteristics } \\
\hline Pure & 226 & $46(20.3 \%)$ & $0.794^{\mathrm{A}}$ & & \\
\hline Mixed race & 25 & $4(16.0 \%)$ & & & \\
\hline \multicolumn{6}{|l|}{ Size of the goat herd } \\
\hline Up to 50 animals & 65 & $4(6.1 \%)$ & $<0.001^{\mathrm{B} *}$ & - & \\
\hline Between 51 and 100 animals & 145 & $46(31.7 \%)$ & & $7.1(2.4-20.6)$ & $<0.001^{*}$ \\
\hline Between 101 and 200 animals & 15 & $0(0.0 \%)$ & & $* *$ & \\
\hline Over 200 animals & 26 & $0(0.0 \%)$ & & $* *$ & \\
\hline \multicolumn{6}{|c|}{ Feeders and drinking troughs for young and adult goats } \\
\hline Yes & 60 & $11(18.3 \%)$ & $0.724^{\mathrm{B}}$ & & \\
\hline No & 191 & $39(20.4 \%)$ & & & \\
\hline \multicolumn{6}{|l|}{ Insect control } \\
\hline Yes & 191 & $39(20.4 \%)$ & $0.724^{\mathrm{B}}$ & & \\
\hline No & 60 & $11(18.3 \%)$ & & & \\
\hline \multicolumn{6}{|l|}{ Cleaning of premises } \\
\hline Yes & 219 & $43(19.6 \%)$ & $0.767^{\mathrm{B}}$ & & \\
\hline Weekly & 32 & $7(21.9 \%)$ & & & \\
\hline \multicolumn{6}{|l|}{ Spare goats are owned by } \\
\hline Yes & 231 & $40(17.3 \%)$ & $<0.001^{\mathrm{B} *}$ & & \\
\hline No & 20 & $10(50.0 \%)$ & & $4.7(1.8-12.2)$ & $0.001^{*}$ \\
\hline \multicolumn{6}{|l|}{ Milking line } \\
\hline Yes & 196 & $34(17.3 \%)$ & $0.054^{\mathrm{B}}$ & & \\
\hline No & 55 & $16(29.1 \%)$ & & $1.9(0.9-3.9)$ & 0.056 \\
\hline \multicolumn{6}{|l|}{ Treatment of clinical mastitis } \\
\hline Yes & 80 & $21(26.2 \%)$ & $0.086^{\mathrm{B}}$ & $1.7(0.9-3.3)$ & 0.088 \\
\hline No & 171 & $29(16.9 \%)$ & & & \\
\hline \multicolumn{6}{|l|}{ Destination of diseased goats } \\
\hline Slaughter & 20 & $10(50.0 \%)$ & $0.088^{\mathrm{B}}$ & $2.4(0.8-6.7)$ & 0.091 \\
\hline Antimicrobial treatment & 65 & $19(29.2 \%)$ & & & \\
\hline \multicolumn{6}{|c|}{ Goats participate in fairs and/or exhibitions } \\
\hline Yes & 65 & $19(29.2 \%)$ & $0.029^{\mathrm{B} *}$ & $2.0(1.0-3.9)$ & $0.031^{*}$ \\
\hline No & 186 & $31(16.7 \%)$ & & & \\
\hline
\end{tabular}


to state that the presence of these clinical signals is decisive for the occurrence of infection by Mycoplasma agalactiae, although other agents may cause these same clinical signals, just as the presence of the agent in goat milk samples does not indicate the occurrence of infection. An association can often occur with other diseases such as Brucellosis, Leptospirosis and Toxoplasmosis, which exhibit similar clinical signals. Even when there is no association between the clinical signs of reproductive disease with the infection by M. agalactiae, an investigation should be undertaken to eliminate the possibility of infection by the agent.

In the analysis of risk factors, an association with the positive effects of PCR for infection by Mycoplasma agalactiae was observed for the following variables: size of the herd $(\mathrm{P}<0.001, \mathrm{OR}=7.1$, I.C. 2.4-20.6), replenishment of animals of the farm $(\mathrm{P}<0.001, \mathrm{OR}=4.7$, I.C.1.8-12.2) and participation of the animals in fairs and exhibitions $(\mathrm{P}=0.029, \mathrm{OR}=2.0$, I.C. 1.0-3.9). As for the size of the herd, the herds which had between 51 and 100 animals showed greater chances of having positive animals than the herds with up to 50 animals (OR=7.1, I.C. 2.4-20.6). In herds in which there is acquisition of animals for breeding stock replenishment there is an increased chance of animals being positive for infection by M. agalactiae when compared with closed herds (OR=4.7, I.C. 1.8-12.2). This is evidence that when replenishment animals do not come from the farms there is a greater possibility of positive animals being introduced in the herds, favoring the dissemination of the agent. In a study done in Jordan, Al-Momani et al. (2008) found that the agent can be introduced by disease-carrying animals from other herds used for reproduction. These same authors reported that other factors can contribute to the occurrence of the agent in the herds, such as: inadequate cleaning of milking equipment and separation of young animals from their mothers. The participation of animals in fairs and exhibitions increased the chances of animals getting infected by M. agalactiae when compared with animals coming from herds which did not take part in these events (OR=2.0, I.C. 1.0-3.9). This result corroborates what was reported by Bandeira et al. (2008), who stated that mycoplasmosis outbreaks in goats in Paraíba and Pernambuco are caused by the participation of animals in fairs and exhibitions and to the introduction of animals coming from the country's Southeastern and Center-Western regions. These authors suggested that the rapid spread of M. agalactiae and probably of other infections is favored by the intense trade and transit of animals from the States of Paraíba, Pernambuco and Rio Grande do Norte. It should be stressed that there are few studies on the risk factors associated with the occurrence of infection by Mycoplasma agalactiae, and further research is needed to investigate others risk factors which may be associated with the infection by this agent.

\section{CONCLUSIONS}

The results of the study allowed the authors to confirm the occurrence of Mycoplasma agalactiae in milk samples from goats coming from Paraíba. However, it is necessary to monitor the dairy goat herds and to raise the awareness of rural producers about the economic relevance of this disease, since it entails severe economic losses for the producers.
The identification of risk factors is indispensable for the adoption of control measures and for the correction of the handling factors in farms which have animals with positive diagnosis, thus avoiding dissemination of the pathogen.

Conflict of interest statement.- The authors have no competing interests.

\section{REFERENCES}

Al-Momani W., Nicholas R.A.J. \& Abo-Shehada M.N. 2008. Risk factors associated with Mycoplasma agalactiae infection of small ruminants in northern Jordan. Prev. Vet. Med. 83(1):1-10. <http://dx.doi.org/10.1016/j. prevetmed.2007.08.003><PMid:17881071>

Alves B.H.L.S., Silva J.G., Mota A.R., Campos A.C., Júnior J.W.P., Santos S.B. \& Mota R.A. 2013. Mycoplasma agalactiae in semen and milk of goat from Pernambuco State, Brazil. Pesq. Vet. Bras. 33(11):1309-1312. <http:// dx.doi.org/10.1590/S0100-736X2013001100004>

Azevedo E.0. 2005. Aspectos clínico epidemiológicos e diagnóstico laboratorial da agalaxia contagiosa dos ovinos e caprinos (ACOC) no Brasil. Doctor of Science, Faculdade de Medicina Veterinária, Universidade Federal Rural de Pernambuco, Recife, PE. 87p.

Azevedo E.O., Alcântara M.D.B., Nascimento E.R., Tabosa I.M., Barreto M.L., Almeida J.F., Araújo M.D.O., Rodrigues A.R.O., Riet-Correa F. \& Castro R.S. 2006. Contagious agalactia by Mycoplasma agalactiae in small ruminants in Brazil: first report. Braz. J. Microbiol. 37(4):576-581. <http://dx.doi. org/10.1590/S1517-83822006000400033>

Azevedo E.O., Silva N.S., Campos A.C., Cordeiro A.A., Mamede A.G., Silva R.B.S. Castro R.S., Nascimento E.R. \& Marinho M.L. 2012. Congenital infection of Mycoplasma agalactiae in goat kids. Arq. Bras. Med. Vet. Zootec. 66(2).

Bandeira D.A., Castro R.S., Azevedo E.O., Nascimento E.R., Melo L.S.S. \& Melo C.B. 2008. Infection by Mycoplasma agalactiae in dairy goat herds in the microregions of Cariri in Paraiba State, Brazil. Arq. Bras. Med. Vet. Zootec. 60(5):1255-1258. <http://dx.doi.org/10.1590/S0102-09352008000500031>

Chazel M., Tardy F., Le Grand D., Calavas D. \& Poumarat F. 2010. Mycoplasmoses of ruminants in France: recent data from the national surveillance network. BMC Vet. Res. 6(1):1-8. <http://dx.doi.org/10.1186/1746-6148-6-32> <PMid:20525406>

Gil M.C., Peña F.J., Hermoso De Mendoza J. \& Gomez L. 2003. Genital lesions in an outbreak of caprine contagious agalactia caused by Mycoplasma agalactiae and Mycoplasma putrefaciens. J. Vet. Med. B 50(10):484-487. <http://dx.doi.org/10.1046/j.0931-1793.2003.00709.x><PMid:14720185>

Gómez-Martín A., Amores J., Paterna A. \& De La Fe C. 2013. Contagious agalactia due to Mycoplasma spp. in small dairy ruminants: epidemiology and prospects for diagnosis and control. Vet. J. 198(1):48-56. <http:// dx.doi.org/10.1016/j.tvjl.2013.04.015> <PMid:23759248>

Hosmer D.W. \& Lemeshow S. 1989. Applied Logistic Regression. John Wiley and Sons, New York. 241p

Madanat A., Zendulková D. \& Pospíšil Z. 2001. Contagious agalactiae of sheep and goats: a review. Acta Vet. Brno 70(4):403-412. <http://dx.doi. org/10.2754/avb200170040403>

Madanat A., Zendulková D., Lány P., Pospíšil Z. \& Číhal P. 2002. Prevalence of Mycoplasma agalactiae antibodies in Czech and Jordanian herds of small ruminants. Acta Vet. Brno 71(1):37-44. <http://dx.doi.org/10.2754/ avb200271010037>

OIE 2013. Contagious agalactia. Manual of Diagnostic Tests and Vaccines for Terrestrial Animals 2017, World Organisation for Animal Health, p.1-10. Available at < http://www.oie.int/fileadmin/Home/eng/Health_standards/ tahm/2.07.04_CONT_AGALACT.pdf>

OIE 2014. Contagious caprine pleuropneumonia. Manual of Diagnostic Tests and Vaccines for Terrestrial Animals 2017, World Organisation for Animal 
Health, p.1-15. Available at <http://www.oie.int/fileadmin/Home/eng/ Health_standards/tahm/2.07.05_CCPP.pdf>

Sampaio I.B.M. 1998. Estatística Aplicada à Experimentação Animal. Fundação de Ensino e Pesquisa em Medicina Veterinária e Zootecnia, Belo Horizonte. 221p.

Santos L.M.M., Pereira C.S., Mansur F.J., Lopes L.A., Campos A.C., Azevedo E.O.,Castro R.S., Barreto M.L., Almeida J.F. \& Nascimento E.R. 2014. Mycoplasma agalactiae outbreak in goat herd of Rio de Janeiro State,
Brazil. Proceedings of the XX Congress of the International Organization for Mycoplasmology, Blumenau, SC, p.22

Thrusfield M. 2004. Epidemiologia Veterinária. 2ª ed. Roca, São Paulo. 572p.

Tola S., Angioi A., Rocchigiani A.M., Idini G., Manunta D., Galleri G. \& Leori G. 1997. Detection of Mycoplasma agalactiae in sheep milk samples by polymerase chain reaction. Vet. Microbiol. 54(1):17-22. <http://dx.doi. org/10.1016/S0378-1135(96)01269-2><PMid:9050167> 